Agnieszka Szplit

Uniwersytet Jana Kochanowskiego, Kielce

E-MAIL: agnieszka.szplit@ujk.edu.pl

Alicja Korzeniecka-Bondar

Uniwersytet w Białymstoku

E-MAIL: alibon@uwb.edu.pl

\title{
Wymiary profesjonalizmu nauczycieli
}

Oddajemy do rąk Czytelników tom „Parezji” poświęcony wymiarom profesjonalizmu nauczycieli, który wpisuje się w dyskusję nad kierunkami zmian w edukacji nauczycieli. Celem jest ukazanie wymiarów profesjonalizmu nauczycieli, różnorodnie opisywanego ze względu na charakter doświadczeń zawodowych i społecznych nauczycieli, odmienne rozumienie ich roli zawodowej czy priorytety ich kształcenia wynikające $\mathrm{z}$ różnic kulturowych i politycznych w różnych krajach. Staramy się ukazać różne oblicza pracy nauczyciela uznanego za profesjonalistę oraz jego rolę w zmieniającej się rzeczywistości edukacyjnej zarówno w Polsce, jak i na świecie. Mamy nadzieję, że zaproponowane międzynarodowe ujęcie przewodniej tematyki podkreśli odmienność i indywidualność nauczyciela profesjonalisty, uzmysłowi niemożność umieszczenia go w ciasno nakreślonych ramach i poszerzy zrozumienie jego roli i wartości. Podążając za opinią Whitty (200o), zakładamy, że zdecydowanie korzystniejsze jest spostrzeganie profesjonalizmu nauczyciela jako zbioru różnorodnych, a nawet przeciwstawnych ujęć, niż zawężenie go do jednej definicji wykluczającej wielorakie możliwości interpretacyjne.

Tytułowa kategoria „profesjonalizmu nauczyciela” odnosi się do takich zachowań, które powszechnie uznane są za zgodne ze standardami w opisywanej profesji (Hargreaves, 1996). Pojawiające się charakterystyki profesjonalnych zachowań nauczycieli przytaczają wiele cech i atrybutów nauczycieli. Dyskusje odbywające się na forach publicznych i podczas konferencji naukowych włączają do tych opisów również wskazanie prowadzenia praktyki popartej badaniami naukowymi i umiejętnościami ich wykorzystania w praktyce, myślenie refleksyjne oraz zdolność tworzenia nowej wiedzy (Coleman, Gallagher i Job, 2012). Oczekuje się od nauczycieli umiejętności współpracy i talentów przywódczych. W badaniach TALIS pojęcie „profesjo- 
nalizmu nauczycieli” operacjonalizuje się jako wiedzę potrzebną do nauczania, autonomię rozumianą jako samodzielność decydowania w zakresie zadań wynikających z pracy zawodowej i umiejętność podejmowania współpracy w kręgach zawodowych przyczyniającej się do wymiany informacji i wsparcia, które pozwalają na zachowanie wysokiej jakości kształcenia (OECD, 2016).

Profesjonalizm nauczyciela utożsamiany jest często z jakością jego pracy, z czego wynika oczekiwanie wypełniania ustalonych standardów, posiadania określonych kompetencji i zakładanego zasobu wiedzy. Nauczycielowi przypisuje się wtedy odpowiedzialność za formę, którą przyjmuje uczenie się w szkole (Barber i Mourshed, 2007), czy wyniki osiągane przez uczniów (Hattie, 2009). Stąd pojawiająca się dyskusja nad możliwościami usprawnienia praktyki i rozwijanie profesjonalnych umiejętności kształcenia na wysokim poziomie. Tak zwany „nowy profesjonalizm” podkreśla konieczność nadążania za zmianami w szkolnictwie dzięki wysokiej jakości pracy nauczyciela, ze szczególnym naciskiem na jego efektywność, odpowiedzialność i zaspokajanie potrzeb osób uczących się (Hargreaves, 2000). Ujęcie to, choć zdecydowanie praktyczne i skuteczne z perspektywy szkoły jako instytucji, spotyka się ze znaczącą krytyką pedagogów piszących o „jakości z wnętrza” (Korthagen, 2008) i osobistym rozwoju nauczyciela.

Ważnym trendem dotyczącym profesjonalizmu nauczyciela jest ujęcie traktujące go jako refleksyjnego praktyka, zdobywającego swoje kompetencje dzięki codziennemu doświadczeniu poddanemu namysłowi (Korzeniecka-Bondar, 2018; Szplit, 2019), autonomicznemu i samodzielnemu w swoich poszukiwaniach i budującemu osobiste teorie. Profesjonalne działanie nauczyciela obejmuje zatem i doskonalenie własnej praktyki, oparte na wnioskach z samodzielnie prowadzonych badań (Boyd, 2016), poparte wiedzą naukową i wiedzą zgromadzoną podczas pracy zawodowej (Urbaniak-Zając, 2016). Profesjonalizm nauczycieli nazywany jest otwartym (Dróżka, 2011), refleksyjnym (Czerepaniak-Walczak, 1997) czy poszerzonym (Donaldson, 2011). Podejście to ujmuje nauczyciela jako gotowego na zmiany, twórczego w działaniu i poszukującego nowych rozwiązań oraz niezmiennie refleksyjnego i aktywnego.

W debacie nad zawodem nauczyciela pojawia się regularnie wymóg stałego rozwoju zawodowego i uczenia się przez całe życie. Współczesny dyskurs podkreśla więc konieczność inwestowania w kształcenie nauczycieli oraz wspomaganie ich rozwoju w ciągu pracy czy doskonalenia zawodowego. Badacze podkreślają wagę procesu „stawania się” nauczycielem, który rozpoczyna się już w chwili podejmowania decyzji dotyczącej wyboru zawodu (Dróżka i Madalińska-Michalak, 2016). 
Nauczyciel profesjonalista to też aktywny uczestnik życia społecznego, często lider dokonujący jego transformacji. Przypisuje mu się ważną rolę społeczną i wskazuje jego uwikłania wynikające z konieczności wypełnienia oczekiwań płynących z różnych środowisk i grup społecznych (Rubacha, 2001). W literaturze pedagogicznej przedstawia się oczekiwanie, że podejmowane przez nauczyciela działania nie będą dotyczyć jedynie własnej praktyki i umiejętności potrzebnych w procesie nauczania, lecz obejmą szerszy kontekst, opierać się będą na współpracy z innymi i wybiegną poza rzeczywistość szkolną (Gołębniak i Zamorska, 2014). Wymaga się od nauczyciela aktywnego udziału we wprowadzaniu zmian w szkołach (Frost i Durrant, 2002) czy nawet zmianach społecznych (Sachs, 2003).

Dyskusja nad rolą nauczyciela we współczesnej edukacji jest szczególnie aktualna $\mathrm{w}$ chwili transformacji procesu nauczania podającego w kierunku konstruktywistycznego uczenia się, czy odchodzenia od systemu zajęć w klasie szkolnej i uczenia się nauczycieli w obliczu pojawiających się wyzwań stawianych przez pracę zdalną. Rozważania te prowadzone mogą być dwojako - z perspektywy obserwatora czy ewaluatora charakteryzującego obserwowane zjawisko bez ingerowania $\mathrm{w}$ nie oraz $-\mathrm{z}$ perspektywy uczestnika procesu zaangażowanego i zmieniającego jego przebieg. W tomie naszym dajemy równoważne miejsce obu ujęciom. Analizujemy głosy opinii publicznej, oddajemy głos edukatorom kształcącym innych nauczycieli i projektującym ich programy kształcenia, pedagogom prowadzącym osobiste rozważania nad profesjonalizmem nauczycieli lub taki dyskurs opisującym, jak również wsłuchujemy się w refleksje samych nauczycieli i prowadzimy ogląd ich zawodowych doświadczeń.

Tom rozpoczyna tekst Anny Babickiej-Wirkus pod tytułem Profesjonalizm nauczyciela a kultura praw dziecka $w$ szkole, poruszający problematykę urzeczywistniania kultury praw dziecka w szkole i roli, jaką w tym procesie odgrywa nauczyciel profesjonalista. Praktykowanie tej kultury w codzienności szkoły jest zadaniem wymagającym posiadania przez nauczyciela nie tylko gruntownej wiedzy na temat praw dziecka, ale także akceptacji tych idei oraz stworzenia możliwości doświadczania i upominania się o nie w szkole. Autorka stwierdza, że akademicki i potoczny dyskurs na temat profesjonalizmu nauczyciela pomija lub marginalnie traktuje ten wymiar, co skutkuje niskim poziomem praktykowania kultury praw dziecka w szkołach, a w dalszej perspektywie może oddziaływać na przygotowanie do życia w demokratycznym społeczeństwie obywatelskim.

O nauczycielskiej "jakości z wnętrza” - rozważania nad "modelem cebuli” Freda Korthagena pisze Agnieszka Szplit. Prezentując koncepcję Korthagena, 
wskazuje jej ugruntowanie w opracowaniach naukowych oraz adekwatność do dyskusji nad zmianami edukacyjnymi i rozważaniami dotyczącymi profesjonalizmu nauczycieli. Bazując na modelu, opisuje profile nauczycieli akademickich wyłonione w toku badań empirycznych (wywiady). Ponadto ukazuje harmonię pomiędzy warstwami tytułowej „cebuli” i drogę "przepływu” nauczycielskiej „jakości z wnętrza” oraz podkreśla rolę wielopoziomowego kształcenia nauczycieli.

Problematykę kształcenia nauczycieli podejmuje Onur Ergünay (Turkey) w artykule Conceptualising Teacher Vision as a Possible Framework for Transformative Teacher Professionalism, w którym konceptualizuje termin „wizja nauczyciela", by następnie zaproponować go jako ramę do tworzenia koncepcji profesjonalnego kształcenia nauczycieli. Dokonując analizy różnych koncepcji kształcenia nauczycieli, poszukuje podzielanych właściwości wizji nauczyciela. Artykuł kończy się zestawem zaleceń dotyczących wykorzystania wizji nauczyciela w kontekście profesjonalizmu nauczyciela.

Design principles for the professional development of teacher educators: Illustrations of narration, dialogue and self-study to tytuł artykułu Bregje de Vries, Anji Swennen i Jurriën Dengerink (the Netherlands) poświęconego prezentacji założeń prowadzonego w Holandii programu rozwoju zawodowego osób kształcących nauczycieli. Ukazane zostały jego elementy składowe i trzy zasady projektowania - badanie narracyjne, dialog i samokształcenie - oraz przykłady opisujące ich znaczenie, zaczerpnięte z ewaluacji programu.

Krytycznej analizy głównych działań i inicjatyw na szczeblu krajowym, podjętych w ciągu czterech dekad (od lat 80. XX wieku do chwili obecnej), mających na celu promowanie profesjonalizacji nauczania w Izraelu i zwiększenie profesjonalizmu izraelskich nauczycieli, dokonały Ruth Zuzovsky i Smadar Donitsa-Schmidt (Izrael) w tekście Professionalization and professionalism of teaching and teachers in Israel.

Michał Paluch w artykule Egzystencjał personalny - ku nowej koncepcji $w$ dydaktyce ogólnej przedstawia propozycję wykorzystania podstawowego terminu antropologii filozoficznej, jakim jest Osoba (osobotwórczość), w celu wydostania się z ciążącej na polskiej dydaktyce ogólnej bezosobowej epistemologii marksistowsko-leninowskiej. Aby zabieg ten uczynić czytelnym, autor podjął się krytycznego spojrzenia na naukową twórczość Wincentego Okonia. Krytyki tej dokonał, bazując, na istocie Człowieka przedstawionej przez Karola Wojtyłę w dziele Osoba i czyn (1969). Artykuł obfituje tym samym w język filozoficzny i wynikające $z$ niego neologizmy, zwroty dawno niestosowane $\mathrm{w}$ polskim dyskursie dydaktycznym. Do takich autorskich pojęć należy „egzystencjał personalny”, akcentujący potrzebę wyodrębnienia 
nauczania jako sposobu „Bycia”, od innych przejawów ludzkiej egzystencji. Wyróżniono trzy egzystencjały personalne, będące wykładnią poziomów uczestnictwa nauczyciela we własnym wykładzie: (1) dydaktyczny (gr. didáskō, nauczam); (2) heurystyczny (gr. heuriskō, odnajduję, poszukując); (3) ginetyczny (gr. ginōskō, poznaję przez doznanie samego siebie).

W dziale Raporty z badań i doświadczeń badaczy i praktyków znalazły się trzy teksty. Zofia Okraj w artykule Ewolucja warsztatu twórczej pracy dydaktycznej nauczycieli akademickich: relacja $z$ badań prezentuje wyniki badań nad doświadczeniami nauczycieli akademickich w twórczej pracy dydaktycznej, w aspekcie dotyczącym jej ewolucji na przestrzeni lat. Badania zostały przeprowadzone przy wykorzystaniu podejścia teoretyczno-metodologicznego The Evolving Systems Approach to Creative Work Howarda E. Grubera. Analiza i interpretacja zebranego materiału badawczego pozwoliła wyróżnić dwie fazy w rozwoju twórczej pracy dydaktycznej: pierwsza - intuicyjna, związana z poszukiwaniem „własnej drogi” w obszarze wybranych podejśćl metod/technik kształcenia; druga - będąca „odnalezieniem przestrzeni dla twórczych rozwiązań dydaktycznych” oraz typowymi dla tego etapu „przejściami między rolami”. W tomie Czytelnik znajdzie, przygotowane przez Oskara Szwabowskiego, studium recenzyjne wydanej w 2019 roku przez Wydawnictwo Difin książki Zofii Okraj Bez szablonu. Twórcza praca dydaktyczna $w$ doświadczeniach nauczycieli akademickich, która dotyczy prezentowanej w artykule problematyki.

Integrating Blogs in Student teachers' Practical Work to tytuł tekstu autorstwa Liat Biberman-Shalev (Israel), w którym autorka dokonuje analizy potencjału tkwiącego w wykorzystywaniu blogów w kształceniu nauczycieli. Tekst zawiera charakterystykę blogów, ich cech i funkcji, oraz przegląd badań dotyczących praktycznego zastosowania i korzyści płynących z blogów w kształceniu nauczycieli oraz niektóre konsekwencje dla osób kształcących nauczycieli.

Wizerunek nauczycieli na wybranych stronach internetowych szkót średnich zrzeszonych $w$ Stowarzyszeniu na rzecz Najstarszych Szkół w Polsce stał się przedmiotem analizy dokonanej przez Anitę Garbat. Analiza dziesięciu stron internetowych szkół pod kątem prezentacji kadry pedagogicznej pozwoliła stwierdzić, że wirtualna przestrzeń szkoły stanowi niewykorzystany obszar $\mathrm{w}$ zakresie ukazywania potencjału merytoryczno-dydaktycznego nauczycieli. Autorka odsłania braki w koncepcji prezentowania wizerunku nauczycieli oraz niedostrzeganie ważności prezentowania nauczycieli jako ludzi wykształconych, o szeregu kwalifikacji oraz pasji i zainteresowań. 
Podjęte wątki nie wyczerpują szerokiej i złożonej problematyki wymiarów profesjonalizmu nauczycieli, stanowią jedynie głos w dyskusji wart kontynuowania i pogłębiania, do czego zapraszamy Czytelników.

\section{BIBLIOGRAFIA}

Barber, M., Mourshed, M. (2007). How the world's best-performing school systems come out on top. London: McKinsey.

Boyd, P. (2016). Realistic Clinical Practice: Proposing an inquiry-based pedagogy for teacher education. W: P. Boyd, A. Szplit (red.), Student Teachers learning Through Inquiry: International Perspectives (s. 11-22). Kraków: Attyka.

Coleman, M.R., Gallagher, J.J., Job, J. (2012). Developing and Sustaining Professionalism Within Gifted Education. Gifted Child Today, s. 27-36.

Czerepaniak-Walczak, M. (1997). Aspekty i źródła profesjonalnej refleksji nauczyciela. Toruń: Edytor.

Donaldson, G. (2011). Teaching Scotland's Future: Report of a Review of Teacher Education in Scotland. Edinburgh: Scottish Government.

Dróżka, W. (2011). Od pewności ku refleksyjności w zawodzie nauczycielskim. Przyczynek do dyskusji. Przegląd Pedagogiczny, 1, 135-150.

Dróżka W., Madalińska-Michalak J. (2016). Droga do zawodu nauczyciela i motywy jej wyboru - w świetle autobiograficznych wypowiedzi studentów studiów pedagogicznych. Forum Oświatowe, 28 (1(55)), s. 161-179.

Frost, D., Durrant, J. (2002). Teachers as Leaders: Exploring the Impact of Teacher-led Development Work. School Leadership and Management, 22(2), 143-161.

Gołębniak, B.D., Zamorska, B. (2014). Nowy profesjonalizm nauczycieli. Podejścia - praktyka - przestrzeń rozwoju. Wrocław: Dolnośląska Szkoła Wyższa.

Hargreaves, A. (2000). Four ages of professionalism and professional learning. Teachers and Teaching: Theory and Practice, 6(2), 151-182.

Hargreaves, A., Goodson, I. (1996). Teachers' professional lives: Aspirations and actualities. W: I. Goodson, A. Hargreaves (red.), Teachers' professional lives (s. 1-27). London: Falmer.

Hattie, J. (2009). Visible Learning. A synthesis of over 800 meta-analyses relating to achievement. London: Routledge.

Korthagen, F., Vasalos, A. (2008). Quality from within as the key to professional development. Referat na spotkaniu American Educational Research Association, New York, March. Pozyskano z: http://post.queensu.ca/ ste/AERA2008/korthagen.pdf, [10.01.2017].

Korzeniecka-Bondar, A. (2018). Codzienny czas w szkole. Fenomenograficzne studium doświadczeń nauczycieli. Kraków: Oficyna Wydawnicza Impuls.

OECD. (2016). Supporting Teacher Professionalism: Insights from Talis 2013. Paris: OECD Publishing.

Rubacha, K. (2001). O społecznej roli nauczyciela w świetle teorii roli indywidualnej Levinsona. Teraźniejszość - Człowiek - Edukacja. Kwartalnik myśli społeczno-pedagogicznej, 4, S. $39-52$.

Sachs J. (2003). The Activist Teaching Profession. Buckingham: Open University Press.

Szplit, A. (2019). Od nowicjusza do eksperta. Rozwój ekspertywności nauczycieli nauczycieli języków obcych. Kielce: Wydawnictwo Uniwersytetu Jana Kochanowskiego.

Urbaniak-Zając, D. (2016). W poszukiwaniu teorii działania profesjonalnego pedagogów. Kraków: Oficyna Wydawnicza Impuls.

Whitty, G. (200o). Teacher professionalism in new times. Journal of In-Service Education, 26(2), 281-295. 